\title{
Product Innovation of Islamic Financial Institutions
}

\author{
Agus Rojak Samsudin ${ }^{1}$ \\ ${ }^{1}$ Ma'had Al-Zaytun, Indramayu, West Java, Indonesia. \\ Email: ghost.rzk@gmail.com
}

\begin{abstract}
:
This article was composed from the fact that the presence of Sharia Financial Institutions (SFC) cannot be separated from the existence of Conventional Financial Institutions. Islamic Bank appeared in the midst of the conventional banking development. It certainly gives the impression product of Islamic Bank is seen as the imitation of conventional banking products. The historical analysis shows that the substantive function of banking operations has been practiced since the early days of Islam. Even the profit and lost sharing principle has been applied from transactions Islamic business transactions (Mu'amalah) in the ancient Arab, which has been explored in the modern era and also legitimized by the Fatwa of DSN MUI (National Sharia Council of Indonesian Ulama Council (NSC-ICU). This institution is often reinterpreting the concept of Islamic business, including the innovation of Islamic Banking products that are derived from the Quran, the Sunna, and Islamic Jurisprudence (al-ljithad).
\end{abstract}

Keywords: Innovation, Islamic Finance, Islamic Banking, Profit and Loss-Sharing, Transaction.

\section{A. INTRODUCTION}

On the economy, the production process plays an important role in determining the extent of human life and prosperity of a nation (Reinert, 1999). The Qur'an has laid a very strong foundation to production (Muhamat, Rosly and Azizan, 2012). In the Qur'an and Sunnah widely demonstrated how Muslims are commanded to work hard to make a living so that they can have a better life, as revealed in Al-Qasas verse 73:

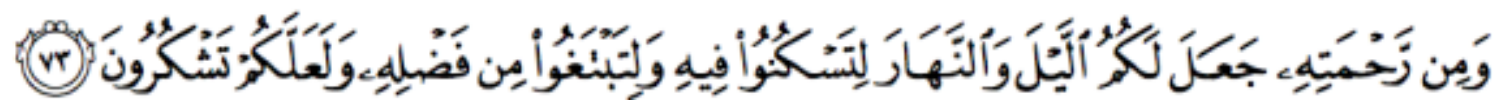

"And out of His mercy He has made for you the night and the day, that you may rest there in, and that you may seek of His grace, and that you may give thanks". [Al Qasas: 73]

The word "ibtaghu" in this verse means the desire (Ali, 2003, Il:1258), the will is earnest to get something that shows the infinite effort. While the word "fadl" (grace) means the economic improvements that make people's lives economically obtain advantages and happiness. This verse shows that the importance of production activities is a fundamental principle in Islamic economics (Cf., Boutayeba, Benhamida and Guesmi, 2014). Pursed production activity in humans and 
existence, welfare distribution that is based on justice and welfare for all human beings on earth (Cf., Athoillah, 2013). Thus, the human interest in line with Islamic morals should be the focus and the target of production activities (Abdullah, Hamali and Abdullah, 2015). In other word a production activity resulting in a product, which must be proportional to the values of the shari'ah and human interest (Deuraseh, 2012).

It requires constant innovation considering human life continue to expand with the growing need for life as a system of life, Islam has set the principles of sharia through khițā b Allah and the Prophet PBUH, including in economic activity (Hassan and Hippler, 2014). Shari'ah principles are the reference Mujtahids in an attempt to keep the taste of sharia in every ijtihā d product (Iqbal, Akhtar and Lodhi, 2014). In Indonesian cotext, the atmosphere applies to institutions such as fatwa of NSCICU of Shari'ah economy, as legulator for sharia financial Institutions (Pasaribu and Ridwan, 2015).

Essentially, product innovation of Sharia Financial Institutions is an ijtihā $d$ in financial management bring to the Shari'a. It is reached by renewing, changing something that already exists or create something new. The word "shari'a" attached to the Sharia Financial Institutions or Islamic bank provides a consequence that every product offered must have compliance of Shariah (Fitriyah and Oktaviana, 2013). In addition, as an Islamic Financial Institutions, the business has a lot to make a breakthrough to a more competitive and commercially viable and, as well as meet the needs of all stakeholders. Thus, innovation is a necessity for a time, times, there will always be changing. The spirit of innovation is in line with the rules: the laws law may be changed according to the changing times, places, circumtances, customary and intentions (Hallaq, Authority, Continuity and Change in Islamic Law, 2004:166).

It is undeniable that the institutional, sharia financial management comes after the growth and development of conventional banks. It suggests that the presence of Shariah Bank is a reactionary phenomenon of the conventional bank financial management practices that promote the application of the system of interest that in some ways Identics with usury (Pita, 2014). One thing that is strongly opposed Islam. The principle of the prohibition of riba is one of the principles in the Islamic economic system. This has implications for bank products sharia in some things, of course, required for innovative and competitive products compete with conventional banks (Athoillah and Al-Hakim, 2013).

By empirically, the business management of the economy (finance) has been done since the time of the Apostle Muhammad in Mecca and Medina (Jamil, 2015), which continued during the Khilafat al Rosyidin, and the Islamic Caliphate daulah afterwards. There are many haditths, athar or ijtihā $d$ of the scholars after the Prophet related to economic transactions (Khalil, 2014). This can be interpreted as an "innovative response" mujtahid to the phenomenon of the economy in the society at that time. The role of scholars can be paired with the role of NSC-ICU as an institution for the activity of sharia financial institutions in Indonesia. Thus, the understanding of history, especially relating to the history of the establishment of the Islamic economic law will be closer products on sharia financial institutions to the values of sharia in Indonesia. 


\section{B. METHODS}

Through an understanding of the history, the background can be seen as a socio-cultural of Islamic laws formulated throughout history, as in the time of the Prophet, companions, next school scholars and so on. Through the analysis of the history of law, the sharia implementation stages can be known of all time, how scholars apply it to answer the question that appears in his day, that it can also emergence of fiqh rules from time to time. This knowledge will encourage scholars of today to reformulate the rules of the new economy, both micro and macro, in particular monetary figh rules that are part of the economic law of Islam.

\section{RESULT AND DISCUSSIONS}

A discussion of product innovation on Sharia Financial Institutions can not be separated from the history of Islamic banking. Because, a product on Sharia financial institutions like the fruit that is worth exploring the tree. Did he really come from the tree of Islam or conventional? In other words, whether the Sharia banking is a new financial institution that is totally unfamiliar and unknown in earlier times. Or whether it is an institution whose foundation has been laid since the early days of Islamic history?

By relating to a product of Islamic financial institutions, historical exploration on it becomes important, because it will determine the next steps. By quoting Karim (2010), in which he stated when the concept of the bank is a new concept for Muslims, they have to start ijtihã $d$ starting from zero. However, if the bank concept is not a new concept, it means that Muslims are familiar even to practice banking functions in the life of the economy, then the process of ijtihā $d$ which do matter will certainly be easier. That means when the treasures of history were not yet putting the principles of financial management, may be the product Sharia financial institutions will be mere imitation product of conventional banks.

\section{Innovation of Sharia Financial Products in the Classical Period}

In fact, Islamic Economics is not a science of reactionary attitude towards the phenomenon of conventional economics. Beginning of its existence is equal to the initial presence of Islam in the face of this earth, because of Islamic economics is an integral part of Islam as a living system (Siddiqui, 2009). Islam is believed to be a road or the concept of life course covers the economy as one of the activities of human life. So, we can say that Islamic economics is a religious activity or worship of economy (Jong, 2008).

As the Messenger of God, Muhammad was a human being, as well as his people who live and work on meeting their needs with economic activity. What is different, he is the messenger of Allah, get a revelation from God. In this position, in addition to being businessmen, Muhammad PBUH also acts as a maker of judicial decisions. He is a major figure, because he was sent to perfect noble character. More specifically morality in economic activity. Thus, all of the words, actions and attitudes, is an innovative response in organizing the economic life of the people of his time (Faizal, Ridhwan, and Kalsom, 2013).

Although the terminology of history at the time put the Arabs as jahiliyyah. In fact, they have been cultured and lived in civilized region. The system adopted for the results of their habits, which has 
been practiced Arabs long before Islam. Some of them are applied in agricultural management agreements such as mukhā bara, muzā ra'a, and musā qa. The profit sharing principle in its development is the fundamental principle of sharia banking business (Sadiq, 2014). Mudaraba concept, also had long been part of their economy (Shafiai, 2011). Where Muhammad (before becoming apostle) also carry out the concept, that is, when he acted as mudarib (investment manager) for Khadijah (Mustofa, 2013). Caliph Umar bin Khatab also invest the money of orphans (Zakariyah, 2014) to the merchants who trade on the trade route between Medina and Iraq. Business partnerships based on a simple system for the results of this kind continue to be practiced for centuries without change in shape at all. In a further development of practice for the results of the stretcher got the legitimacy of the Prophet.

Some of muamalah practices in Arab society enhanced through the bans and orders, while others are not given a special statement. This implies that economic practice is allowed. That phenomenon into the background to the rules of fiqh which reads " The law of origin in all forms is mu'ā mala be made unless there is proof that forbid it (Wahdan and Nofal, 2013, Al-'Ubaidi, 2011; Cf., Suyuthi, 1983/1403:60). Banking institutions are not recognized by the Islamic community, either at the time of the Prophet, al Khulafa al Rosyidin, Umayyad, Abbasid dynasty as well. However, the functions of banks that accept deposits, funds and transfer funds have been prevalent at the time (Wibowo, Setyono dan Abadi, 2013).

In his article titled Islamic Banking, Sami Hamoud as quoted by Karim (2010), revealed that, during the Mecca period, Muhammad PBUH known by the nickname al-Amin, believed by the people of Makkah for receiving deposits treasure. So, at a time before moving to Medina, he asked Ali bin Abi Talib to restore all of the deposit to the owner (Naeem, 2013).

In one story, A friend of the Prophet, Zubayr ibn al-Awam r.a., prefer not to receive entrusted property. He would prefer to receive it in the form of loans. Zubair action raises different implications, ie, first, to take the money as a loan, he has the right to utilize, second, because of the loan, he is obliged to return it intact. In the other story, mentioned Ibn Abbas r.a. also been transferring money to Kuffah and Abdullah bin Zubair transferring money from Mecca to his sister Mis'ab bin Zubair r.a. living in Iraq (Fajri, 2008).

The use of checks is also known broadly in line with the increase in trade between the country Sham and Yemen (Mardiana, 2014) which lasted at least two times a year. Even during his reign, Caliph Omar bin al-Khatab r.a. use a check to pay to those who deserve it (Inayati, 2013). By using this check, they took the grain in the Baitul Mal when it was imported from Egypt. In addition, the provision of capital for working capital based on profit sharing such as mudaraba, mukhā bara, muzā ra'a, and musā qa, has been known since the beginning of the Muhajireen and the Anshar. Therefore, the financing is done by contract in accordance with the principles of sharia has become part of a tradition of Muslims since the time of Prophet Muhammad PBUH. Such practices treasure receives deposits, lend money for consumption purposes and for business purposes, as well as transferring money, it has been common practice since the time of Prophet Muhammad SAW. Thus, the main functions of modern banking in particular Islamic bank, which received the deposit, funds and transfer funds that have sharia compliance has become an integral part of the lives of Muslims, even since the time of Prophet Muhammad PBUH. where he served as a supervisor. Even, 
according to S. Praja Juhaya, some modern banking terms derived from the treasures of the science of jurisprudence, such as credit terms (English: credit; Romans: credo) were taken from the term qard. Credit in English means lending money; credo means trust; whereas qard in jurisprudence means lend money on the basis of trust. Similarly, the term check (English: check; France: Cheque) were taken from the term saq (suquq). șukū $k$ in Arabic means the market, while the pay check is a tool commonly used in the market.

At the Time of Prophet PBUH. There are individuals who have been fulfilling their banking functions even though the individual is not performing all banking functions. A number of companions who carry out the institution function, i.e. receives deposits, carry out the lending and borrowing money, there is performing the function of borrowing and lending and some are providing working capital.

Only later, at the time of the Abbasids, the three banking functions performed by a single individual. Banks began to grow rapidly when many currencies circulating at that time so it needs special skills to distinguish between one currency with another currency. This is necessary because each currency has a different precious metal content so as to have different values. People who have specialized expertise is called naqid, sarraf, and jihbiz. It is the forerunner of the practice of currency exchange (money changers). The term jihbiz known since the time of Muawiyah (661-680M) who is actually borrowed from Persian, kahbad or kihbud. In the reign of Sasanid, this term is used for those who were assigned to collect the land tax.

The role of bankers in the Abbasid era began to be popular in the reign of Muqtadir (908-932M). At that time, almost every vizier has bankers themselves. For example, Ibn Imran ibn Furat appointed Aaron and Joseph Ibn Wahab as a banker. Then appoint Ali Ibn Abi Isa ibn Isa, Hamid ibn Ibrahim ibn Wahab pointed Yuhana, even Abdullah al-Baridi have three bankers at once: two Jewish and one Christian.

The progress of banking practice at that time was marked by the release of the SAQ (check) with an area as a medium of payment. In fact, the role of bankers has covered three aspects, namely accepting deposits, distribute, and transfer money. In the latter case, the money can be transferred from one country to another without the need to physically move the money. The money changer who has set up offices in many countries have started the use of checks as a medium for the transfer of money and other payment activities. In the history of Islamic banking, is Sayf al-Dawla al-Hamdani noted as the first to issue a check for the purpose of clearing between Baghdad (Iraq) and Aleppo (Syiria). So, the presence of currency exchange and check is an innovation in sharia financial practices at the time.

\section{Innovation of Sharia Financial Products in the Modern Period}

The basics of a contract that became a pillar in the banking operations sharia, actually get the settings. However, it takes the human actions that the existing concept can be implemented. It calls for formal financial institutions that are comply with sharia as the container value in applying the principles and values of Islam in real life.

The efforts initial application of the profit and loss sharing recorded in Pakistan and Malaysia around 1940. Their efforts manage the pilgrim funds in a non-conventional. However, the history of sharia banking and banking products first took place in Cairo, Egypt with the establishment of Islamic Rural 
Bank in the village of Mit Ghamr in 1963. Then, the first Islamic bank that is private is Dubai Islamic Bank was established in 1975 by a group of Muslim businessmen from various countries. In 1977, the two standing Islamic Bank under the name of Faysal Bank in Egypt and in the same year established the Kuwait Finance Hause.

The development of Shariah Banks internationally starting with the Foreign Ministers Session held Organization of Islamic Conference in Karachi, Pakistan, December 1970. Egypt submitted a proposal for the establishment of the International Islamic bank trade and development (International Islamic Bank for Trade and Development) as well as the proposal of establishment Islamic Bank Federation (Federation of Islamic Bank). The contents of the proposal essentially are proposing a financial system based on the interest should be replaced with a system of cooperation with the profit-sharing scheme on profits and losses. After getting the discussion of eighteen of the Islamic State, the proposal finally accepted. Assembly approved a plan establishing the International Islamic Bank and the Federation of Islamic banks. New in the 1975 session of the Ministry of Finance of the OIC approved the establishment, in Jeddah, The Islamic Development Bank (IDB).

Enforcement of Islamic economic system is the most phenomenal happening in Sudan. When it was first Islamic law applied in September 1983 sparked the government's General Numeiry Islamization of Sudan economy and financial system. As a follow up of the law, commercial banks are not yet operating of Shariah must be converted into Islamic bank in September 1984.

Sharia banking system in Sudan implement all of the contract that has been agreed by most scholars, in accordance with the principles of the sharia for the shari'a financial products and instruments offered to customers. All of the contract includes the contract for funding, financing and banking services. In general, it can be explained as follows:

a. Funding: Demand, savings, deposits / Investment General and Special Investment Deposits

b. Financing, there are 24 product financing, namely: Working Capital, Investment, Tax Financing, Procurement Investment in Foreign Trade Financing, Financing Goods of Imported, Agricultural Financing, Equipment Financing. Financing fixed assets, financing the stock of goods, finance, procurement Consumption, Property Financing, financing home I shop / office, financing motor vehicles, financing computer, Financing Plant and machinery, Product Order Investments, renovation, financing Bailout, Loan Virtue, Pawn and takeover I transfere Service

c. Banking Services, includes two things:

1) Services product offered by the Sharia banking Sudan and varied enough to meet the needs of business and personal, Contract used by the services of these products mostly using contract says, wakā la and kafā la. Among its products, among others, ATM Cards, Cards Hajj / Umrah, SMS Banking, bill payment, electronic salary payment, sale and purchase of foreign currency, bank Guarantee, $L / C$ in the country and the L / C.

2) Operational services, amongst its products are: deposit clearing, inter-city clearing, RTGS, Collection, Transfer, Transfer Foreign exchange, import Tax Online tax and bank references. The contract used for the services of these products mostly using wakalah. 


\section{Innovation of Sharia Financial Products in Indonesia}

Product Innovation of Islamic financial institutions in Indonesia was initiated in 1991 after the establishment of Bank Muamalat Indonesia (BMI) as the only commercial bank conducting business based on the principle of profit sharing. Introductions bank based on the principle of profit sharing in the positive law is through Act No. 7 of 1992 on Banking and Government Regulation No. 72 of 1992 concerning Bank Based on Principles of Sharing.

Thus since 1992 the Indonesian banking industry is technically juridical already familiar with the term Bank Based on Principles of Sharing. However, on the other hand we have seen that Islamic banks in operation is not solely based on the principle of sharing, but there are a number of other Islamic traditional contract that can be implemented in practice meant interest-free bank. Many traditional Muslim contract, or often referred to as Islamic principles, is an instrument that replaces the conventional system of interest (ribā'), uncertainty (gharar), gambling (maysir), and vanity which are elements that are prohibited in Islam. Furthermore, Shari'ah banking products as stipulated in Law No. 21 of 2008 concerning Islamic banking is an elaboration of the basic concepts of Islamic Shari'a conducted by the NSC-ICU, both of which refer directly to the Qur'an and the Hadith as well as to the literature of Islamic law (figh).

NSC-ICU was given the responsibility to handle all issues related to the activities of Islamic financial institutions and increase public awareness of the economic and financial affair. NSC-ICU actively contributes in broadening the scope of Islamic financial services by providing regulatory support for this industry. In April 2000, the NSC-ICU Fatwa issued 12 related to the contract and Islamic products offered by Islamic banks and other financial institutions.

In 2000, the Jakarta Stock Exchange, along with Danareksa Investment Management (DIM), launched the Jakarta Islamic Index (JII) consisting of blue chip stocks that have sharia compliance. Corporate Sukuk issuance is another great achievement in the Islamic finance industry in Indonesia. This occurs when Indosat (telecommunications company) published the first Sukuk (based on the Mudharabah) in 2002. This was followed by other corporations, namely Matahari Putra Prima, which issued its Sukuk ljarah in 2004. important contribution governments realized in 2008 when the House of Representatives People issued Law No. Sukuk 19 of 2008 and the Islamic Banking Act No. 21 Year 2008. The first Sukuk issued in 2008, followed by Retail Sukuk first in the world in 2009. The other major development occurred in 2011 when the NSC-ICU issued a Fatwa No. 80 / DSN-MUI / III / 2011 that regulate the world's first in a stock transaction that has sharia compliance in general market Stock Exchange.

The more complex the problems facing Islamic Financial Institutions today demand increasingly responsive NSC-ICU against a range of innovative products needed by society. Until 2015 no less than 100 NSC-ICU fatwas have been issued. Lastly is the fatwa 100 / DSN-MUI / XII / 2015 on Guidelines for Voucher Transactions Multi Benefits Sharia. All the NSC-ICU fatwa must be a basic reference for Islamic financial institutions in the innovation of its products.

Nevertheless, Fatwa issued by NSC-ICU is not positive law, as fatwas issued by the NSC-ICU in other fields. So that the fatwas issued by NSC-ICU be valid and binding as to which positive law in Indonesia, then in Act 21 of 2008 About Islamic Banking noted that fatwas issued NSC-ICU can be followed up as Bank Regulation in Indonesia. Thus, no legally binding between the fatwa issued by the NSC-ICU positive law in the form of regulation issued by Bank Indonesia. This relationship shows 
how the role of fatwa institution in Indonesia is very significant and strategic in building and advancing Islamic Financial Institutions.

While the Financial Services Authority (FSA) as a supervisor at a time regulator of financial institutions in late 2015 through SEOJK No. 36 / SEOJK.03 / 2015 released a number of products and activities of Sharia Commercial Bank and Sharia Business Unit at Islamic Financial Institutions, as follows:

a. Fund raising activities include:

1) Deposits (Demand, Savings);

2) Investments (Demand, Savings, Deposits);

3) Issuance of Certificate of Deposit Sharia;

4) Funding Received;

5) Including the Issuance of Sharia Islamic Securities Equity Features;

6) Asset Securitization; and

7) Other fund-raising activities commonly conducted by the Bank that are not contrary to the positive laws and Sharia.

b. Trade financing include:

1) International Trade Financing Through Issuance and Receipt of Domestic Letter of Credit;

2) Financing Export Import Using Letters of Credit (L / C);

3) Import Export Financing Without Using L / C; and

4) Trade financing activities (trade finance) more commonly done by the Bank that are not contrary to the positive laws and Sharia.

c. Treasury activities include:

1) Trade Foreign Banknotes (Banknotes);

2) Cash Transaction or Transactions Spot Foreign Exchange;

3) Hedging Transactions on Sharia based Exchange; and

4) Other treasury activities commonly conducted by the Bank which do not conflict with positive laws and Sharia.

d. Agency and co-operation include:

1) Sharia Mutual Fund Sales Agent;

2) Sharia Sales Agent Securities Issued by the Government;

3) Marketing Partnership With Islamic Insurance Company (Bancassurance) Business Reference Model, Distribution, and Integration;

4) Payment Point; and

5) The agency or other cooperation activities commonly conducted by the Bank that is not contrary to the positive laws and Sharia.

e. Activities and electronic payment systems include:

1) Clearing;

2) The Operator Final Settlement Transaction Bank (Settlement);

3) Operator Transfer Funds;

4) Payment Instrument Operator Card Cards Among Others Automatic Teller Machines (ATM), Debit Card, and Card Financing (Sharia Card);

5) Operators of Electronic Money (e-Money);

6) Phone Banking;

7) SMS Banking; 
8) Mobile Banking;

9) Internet Banking; and

10) Activities of payment and electronic banking systems more commonly done by the Bank that are not contrary to the positive laws and Sharia.

f. Other activities Other activities include activities such as:

1) Provision of Safe Deposit Box (SDB);

2) Traveller's Cheques (TC);

3) Payment of Employee Salaries Bulk (Payroll);

4) Cash Management;

5) Customer Service Excellent;

6) The Custodian;

7) Trustee;

8) With Care Management (Trust);

9) Virtual Account;

10) Cash Pick Up And Delivery;

11) Escrow Agent;

12) Bank Guarantee;

13) Services outside the office in the Context of Inclusive Finance (Smart Code); and

14) Other activities commonly conducted by the Bank that are not contrary to the positive laws and Sharia.

\section{CONCLUSION}

Tracking the history of the product innovation of Islamic financial institutions should reinforce the understanding of the urgency of the principles of sharia in fostering Islamic economic system, which has been laid Muhammad PBUH, as the foundation of every ijtihã $d$ the practices of the economy of Arab society at the time. The presence of Islamic banks is not a reactionary phenomenon to the existence of conventional banks. The historical fact substantially proved that banking practices have been presented since the early days of Islam, although institutionally sharia banks emerged after the presence of conventional banks. There is a similar atmosphere behind the emergence of sharia bank, in which he comes to offer the concept of lost and profit sharing as an answer to the concept of usury that is practiced conventional banks. Things which happened in the early days of Islam when the Prophet dealing with the system of usury practiced Jahiliyyah Arab society. Thus, in the framework of the history of the establishment of Islamic law, the principle of profit-sharing (lost and profit sharing) has got the legitimacy of the Prophet PBUH.

In the development, profit sharing principle applied in many mu'amalah contract at the time, such as mudaraba, musharaka, mukhubarah musaqah and others. It certainly should be a reference mujtahid scholars and institutions fatwa, such as ijtihā $d$ of NSC-ICU in designing sharia based banking products. Meanwhile, ijtihādof NSC-ICU in relation to sharia based banking products can be the meaningful innovation in the application of Islamic law and make them competitive. So that, the society as a whole can accept them gladly, because their faith is maintained in a perfect and their economic activity remains favorable. 


\section{Reference}

Abdullah, Johari Bin; Hamali, Jamil Haji; Abdullah, Firdaus. (2015). "Success Strategies in Islamic Marketing Mix". International Journal of Business and Society, Vol. 16 No. 3, pp. 480 - 499.

Al-'Ubaidi, Sa'id Ali Muhammad. (2011). Al-Iqtișā d Al-Islā mī, Oman, Dar Dajlah.

Ali, Muhammad Mohar. (2003). "A Word for Word: Meaning of the Qur'an”, Vol. II, Ipswich, Jam'iyat Minhaaj Ihya' Al-Sunnah.

Athoillah, M. Anton and Al-Hakim, Sofyan. (2013). "Reinterpreting the Ratio legis of the Prohibition of Usury". Middle-East Journal of Scientific Research. 14 (10), pp. 1390-1400, http://dx.doi.org/10.5829/idosi.mejsr.2013.14.10.2187

Athoillah, Mohamad Anton, (2013), "Zakat as an Instrument of Eradicating Poverty (Indonesian Case)". International Journal of Nusantara Islam. Vol. 1 No. 1, pp. 73-85; https://dx.doi.org/10.15575/ijni.v1i1.37

Boutayeba, Faiçal; Benhamida, Mohammed; Guesmi, Souad. (2014). "Ethics in Islamic Economics", Annales. Ethics, Economic Life. 2014, vol. 17, no. 4, pp. 111-121.

Deuraseh, Nurdeng. (2012). "New Essential Values of Daruriyyah (Necessities) of The Objectives of Islamic Law (Maqasid Al-Shari ah). Jurnal Hadhari. 4 (2), pp. 107 - 116

Faizal, P. R. M.; Ridhwan, A. A. M. and Kalsom, A. W. (2013). "The Entrepreneurs Characteristic from al-Quran and al-Hadis". International Journal of Trade, Economics and Finance. Vol. 4, No. 4, pp. 191-196, http://dx.doi.org/10.7763/IJTEF.2013.V4.284

Fajri, Rahmat. (2008). "Sejarah Keuangan Islam". Aplikasia, Jurnal Aplikasi Ilmu-ilmu Agama. Vol. IX, No. 2, pp. 173-194

Fitriyah and Ulfi Kartika Oktaviana. (2013). Relevance of Financial Performance and Good Corporate Governance Determinant of Sustainaibility Corporate Social Responsibility Disclousure in Islamic Bank in Indonesia. International Journal of Nusantara Islam, Vol. I. Number 2, 2013., pp. 23-37, https://dx.doi.org/10.15575/ijni.v1i2.23

Hassan, M. Kabir and Hippler, William J. (2014). "Entrepreneurship and Islam: An Overview”. Econ Journal Watch, 11(2), pp. 170-178

Iqbal, Anam; Akhtar, Shahzad; Lodhi, Rab Nawaz. (2014). "Islamic Financial Product Development In The Pakistan: Shariah Analysis". European Journal of Accounting Auditing and Finanace Research, Vol.2, No.10, pp.112-121.

Jamil, Muhammad Yousaf. (2015). "Islamic Perspective of Leadership: A Role Model for Today's CEOs". Journal of Islamic Thought and Civilization, Volume 5, Issue II, pp. 24-45 
Jong, Eelke de. (2008). "Religious Values and Economic Growth: A review and assessment of recent studies". NiCE Working Paper 08-111, Nijmegen Center for Economics (NiCE), Institute for Management Research, Radboud University Nijmegen.

Karim, Adiwarman A. (2010). Bank Islam, Analisis Fiqh dan keuangan. Jakarta: PT. Raja Grafindo Persada.

Khalil, Abdul Wahab. (2014). "Transfer Dana Dalam Perspektif Hukum Islam”. Al-Hurriyah, Vol. 15, No. 2, pp. 23-41.

Mardiana, Andi. (2014). "Uang Dalam Ekonomi Islam”. Jurnal Al-Buhuts, Volume. 10 Nomor 1, pp. 91-109.

Muhamat, Amirul Afif bin; Rosly, Hardi Emrie bin and Azizan, Norfaridah binti Ali. (2012). "The Development of Ethical Banking Concept amongst the Malaysian Islamic Banks". Jurnal Pengurusan Awam, Volume 9, No. 1, 2012, pp. 119-129.

Mustofa. (2013). "Enterpreneursip Syariah: (Menggali Nilai-Nilai Dasar Manajemen Bisnis Rasulullah). Al-Mizan, Vol 9, No 1, pp. 29-46.

Pasaribu, Fajar and Ridwan, Muhammad. (2015). "The Extraordinary Solution for Indonesia Economic Crisis: Shariah Capital Market". Journal of Islamic Banking and Finance, Vol. 3, No. 2, pp. 47-56, http://dx.doi.org/10.15640/jibf.v3n2a5

Pita, Agnélio M. P. Chicava. (2014). "Some Issues to Consider when Regulating Islamic Banking Business in Secular Countries". Journal of Islamic Banking and Finance, Vol. 2, No. 1, pp. 389-405.

Reinert, Erik S. (1999). "The role of the state in economic growth". Journal of Economic Studies, Vol. 26 No. 4/5, pp. 268-326, https://dx.doi.org/10.1108/01443589910284903

Rozalinda. (2015). Ekonomi Islam Teori dan Aplikasinya pada Aktifitas Ekonomi, Jakarta, PT. Raja Grafindo Persada.

Sadiq, Ebtisam. (2014). "Islam and Human Life: Beyond Ancient Needs". The Journal of Business Inquiry, 13, Issue 1 (Special Issue), pp. 12-26.

Shafiai, Muhammad Hakimi Bin Mohd. (2011). "Crafting the agricultural product and loss sharing (aPLS) in the place of the profit and loss (PLS) for Islamic agricultural finance', Center for Southeast Asian Studies, Kyoto University,

Siddiqui, Saif. (2009). "Islamic Economic System and Poverty Reduction" SSRN: https://ssrn.com/abstract=1332618 or http://dx.doi.org/10.2139/ssrn.1332618

Suyuthi, Jalal al-Din. (1983/1403). al-Asybah wa al-Nazhair, Beyrut, Dar al-Kutub. 
Undang-undang No. 21 Tahun 2008 tentang Perbankan Syariah. (Act No. 21 of 2008)

Wahdan, Abdallah Abu and Nofal, Ahmed. (2013). "Conditions of Installment Sale in Islamic Jurisprudence". An-Najah University Journal for Research - B (Humanities), Volume 27, Issue 2, pp. 417-446.

Wibowo, M. Ghafur; Setyono, Joko; Abadi, Kurnia Rahman. (2013). "Accounting Treatment for Unrestricted Investment Deposits and its Implication to Islamic Financial Institution". Global Review of Islamic Economics and Business, Vol. 1, No.2, pp. 119-132.

Zakariyah, Luqman. (2014). "Jurisprudential Analysis of Maqasid al-Shariah in Managing Mosques Funds: A Case Study of Tabung Masjid (TM) in Malaysia'. The First International Conference on Islamic Finance: Innovation Instruments- Issues of Implementation and Future Challenges, University of Sharjah, United Arab Emirates. 